\title{
Corruption and Combating Corruption: A Framework for Peace, Human Rights and Sustainable Development in Post-Independent Africa
}

\section{Eric Che Muma}

\author{
Department of Public Law and Public International Law, \\ Teaching Assistant at Giessen Graduate Centre for Social Sciences, \\ Business, Economics and Law, \\ Justus Liebig University Giessen, Germany
}

Doi: $10.2478 / \mathrm{mjss}-2018-0134$

\begin{abstract}
Since the introduction of democratic reforms in post-independent Africa, most states have been battling corruption to guarantee sustainable peace, human rights and development. Because of the devastating effects of corruption on the realisation of peace, human rights and sustainable development, the world at large and Africa in particular, has strived to fight against corruption with several states adopting national anti-corruption legislation and specialised bodies. Despite international and national efforts to combat corruption, the practice still remains visible in most African states without any effective accountability or transparency in decision-making processes by the various institutions charged with corruption issues. This has further hindered global peace, the effective enjoyment of human rights and sustainable development in the continent. This paper aims to examine the concept of corruption and combating corruption and its impact on peace, human rights and sustainable development in post-independent Africa with a particular focus on Cameroon. It reveals that despite international and national efforts, corruption still remains an obstacle to global peace in Africa requiring a more proactive means among states to achieve economic development. The paper takes into consideration specific socio-economic challenges posed by corruption and the way forward for a united Africa to combat corruption to pull the continent out of poverty, hunger and instability, and to transform it into a better continent for peace, human rights and sustainable development.
\end{abstract}

Keywords: Corruption, peace, human rights, sustainable development, post-independent Africa

\section{Introduction}

With the introduction of democratic reforms in post-independent Africa, mainly after the 1990s, peace, human rights and sustainable development were viewed by many as a great move towards the enhancement of democracy and a future prospect for transforming African states from authoritarianism and corruption towards the attainment of the UN Development Goals (Goal 16, 2030 Agenda for Sustainable Development, 2015). This requires establishing effective institutions of accountability and transparency in the fight against corruption. Despite several democratic reforms, post-independent Africa is impeded by corruption scandals, poverty, hunger, conflicts and underdevelopment: it is all because of lack of good governance, the rule of law and effective and independent democratic institutions to ensure accountability of state officials and those charged with corruption issues. The lack of effective and united anti-corruption measures to curb corruption in post-independent Africa has left untold sufferings in the lives of many, especially the poor and younger children who go to bed with empty stomachs while the most corrupt officials live extravagantly. As commonly said, 'a hungry man is always an angry man'. Those who face hunger as a result of corruption are more often exposed to conflicts.

Since the achievement of independence in 1960, corruption has subjected most African states 
to untold sufferings and conflicts, jeopardising peace, human rights and sustainable development in the continent. These fundamental values or principles are interdependent and indivisible implying that there can be no sustainable development without peace and no peace without sustainable development and no human rights without peace and sustainable development. Economic resources which are meant to ensure development and create employment opportunities and to enforce human rights institutions in most African states have been used for private gains through theft and tax evasion. As stated by the United Nations Development Programme (UNDP), corruption, theft and tax evasion cost about $\$ 1.5$ trillion for developing countries per year. This amount could be used to uplift the economic conditions of those who are living on less than $\$ 1.25$ a day for the last six years (UNDP, Support to the Implementation of the Sustainable Development Goals, 2016). However, the rate of children leaving primary school in conflict-affected countries climbed to $50 \%$ in 2011 , which accounts for 28.5 million children, showing the impact of unstable societies on one of the major goals of the post-2015 agenda on education (Goal 4, Education in the Post 2015 Sustainable Development Agenda, 2015). The devastating impact of corruption on peace, human rights and sustainable development in post-independent Africa and Cameroon, in particular, are beyond imagination. Although the rise in corruption can be tilted towards government's failure to effectively implement democratic reforms and policies, the absence of a practical separation of powers to enable adequate checks and balances within the administration is also a cause for concern. It is evident that a more universal and proactive approach is needed to address corruption in Africa in order to guarantee peace, human rights and sustainable development as agreed by the comity of states.

\section{The Concept of Corruption}

The term corruption in common legal parlance is a criminal act that endangers future prospect for sustainable development and a positive transformation in post-independent Africa. The concept is derived from the maxim curruptus, which means to break (Kolawole, 2014). Although there hasn't been any unique definition of the concept, it is commonly defined as a criminal offence consisting of a person soliciting, offering, giving or accepting from another, for himself or for any other person, any gratification, offer, or promise, gifts or any advantage in order to do, to delay or to abstain from doing an act in the exercise of his duties (Cameroon Bar Association, 2015). While a universally accepted definition is necessary, it is very difficult due to its broad nature. As suggested, the search for a unique definition of corruption is like the pursuit of the Holy Grail, endless, exhausting and ultimately futile (Kolawole, 2014). According to Transparency International (TI), corruption is the abuse of entrusted power for private gains which destroys the basic rights of hundreds of millions of people across the world with devastating consequences on the services provided by public institutions and undermines the prospect for a better life for the future generation (Transparency International, 2018, Kalawole, 2014). Although corruption exists in several countries around the globe, Africa seems to be the most dangerous continent where this menace is uncontrollable.

As Oluwaseung (2013) put it, corruption is widespread in African states and because of its diverse forms, it is extremely difficult, if not impossible, to measure it. Corruption has been classified into petty and grand corruption and undermines humanitarian assistance, poverty alleviation, human development and security (Cameroon Bar Association, 2015, Tavanti, 2013 Kimaro, 2014). Petty corruption involves bribery, extortion, nepotism, fake and forgery, abuse of authority, unlike grand corruption which is practised for enrichment purposes and is part of a dynamic of wealth accumulation by judicial officials in the form of payment of bribes, public funds misappropriation, unlawful charging of interest and fraudulent orders(Cameroon Bar Association, 2015). As stated by Patrick Lumumba (2014), in Africa, some of the causes of corruption include the negative colonial legacy, poor leadership, politics of the belly, omnipotent state, greed and selfishness, clientelism and patronage nepotism, absence of popular participation of the public in government, weak institutions of governance, lack of accountability and transparency, lack of political will, weak ethical values, centralist nature of the state and concentration of state power, weak judicial system and constant insecurity and conflicts.

However, in as much as I agree with Lumumba on the varied causes of corruption 
enumerated in post-independent Africa, I hesitate to emphasise on poor colonial legacy. This is because most African states since independence, have gone as far as to ameliorate the colonial legacies inherited from their predecessors to meet present-day societal changes and to embrace democracy and effective institutional accountability. Of Course, there are others who have deliberately refused to change from negative colonial legacy just to remain in power for life, creating widespread mismanagement of state resources and failing economic development. In Cameroon, for instance, the act of corruption has been described as pandemic and uncontrollable under the incumbent regime and political and bureaucratic corruption has become institutionalized (Fombad, 2008, Fombad, 2000). Corruption remains one of the major causes of delays observed in the multisector development of the state.

Despite international pressure and numerous instruments and mechanisms instituted to fight against corruption, the phenomenon still remains a constant practice of everyday life. It is described as an endemic cancer-worm that is deeply-rooted in all facets of public and private life. From administrative officials, through the courts of law and the police, right down to the private sector, fraud, nepotism, embezzlement and bribery are part and parcel of daily life (Ferim, 2010) According to the $\mathrm{TI}$ index report for 2017, several countries in Africa show a high burden of corruption than countries in the Global North with Cameroon ranking 153 out of 180 countries in total (Transparency International Corruption Perception Index, 2017, Hailbronner, 2016). In the past years, for instance, in 1996, Cameroon was ranked 49(Transparency International Perception Index, 1996) unlike the case in 2008 to 2017. Although the increased rate of corruption in most countries around the globe can be tilted towards the lack of peace and poverty due to frequent conflicts or wars as it is the case in Syria, DR. Congo and the Central African Republic, it can be argued that the lack of commitment and effective institutions of accountability is also posing a great challenge in combating corruption and transforming the African continent into a better place for the future generation. An illustration of the 2017 corruption perception index for some selected countries will reveal the truth of the practice in Africa.

Table: Post-independent Africa corruption perception indexes 2017

\begin{tabular}{|c|l|c|c|c|}
\hline No & Countries & IPC/100\% Score & Rank & No. of Countries \\
\hline 1 & South Africa & 43 & 71 & 180 \\
\hline 2 & Burkina Faso & 42 & 74 & 180 \\
\hline 3 & Ghana & 40 & 81 & 180 \\
\hline 4 & Ethiopia & 35 & 107 & 180 \\
\hline 5 & Tanzania & 36 & 103 & 180 \\
\hline 6 & Kenya & 28 & 143 & 180 \\
\hline 7 & Nigeria & 27 & 148 & 180 \\
\hline 8 & Zimbabwe & 22 & 157 & 180 \\
\hline 9 & D.R Congo & 21 & 161 & 180 \\
\hline 10 & Cameroon & 25 & 153 & 180 \\
\hline 11 & Chad & 20 & 165 & 180 \\
\hline
\end{tabular}

Source: Transparency International <https://www.transparency.org/news/feature/corruption _perceptions_index_2017>

The above chart shows the corruption perception index for 11 selected countries in postindependent Africa in 2017. It reveals that the country with the lowest corruption ranking is South Africa with a score of 71 out of 180 countries in total and Chad represents the highest corrupt country with the highest ranking of 165 out of 180 . Unlike New Zealand, Denmark, Finland and Norway ranking 1, 2, 3 and 3 with percentage scores of 89, 88, 85 and 85 in 2017, Africa in general and Cameroon in particular, though - corruption is not as high as in the case of Chad(165) still reveals a high rate of endemic corruption. This can be further illustrated with due consideration of its ranking position from 2008 to 2017 in figure 2. 


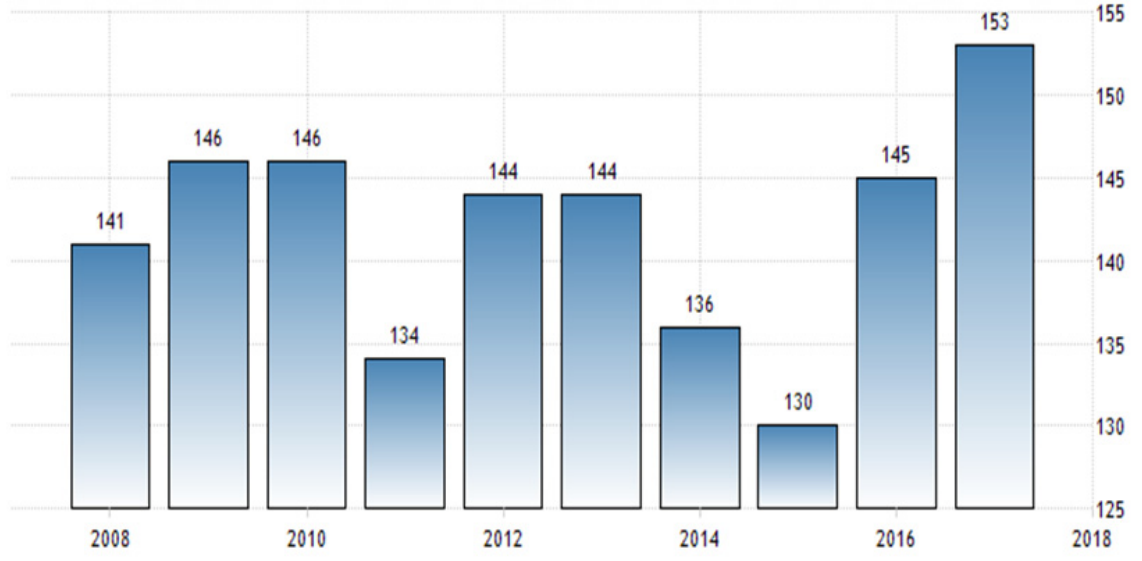

Figure 2 considers Cameroon as a case study on corruption from 2008 to 2017. The figure shows a high fluctuating rate of endemic corruption. Although the country experiences a drastic fall in the rate of corruption in 2011 and 2015, recent statistics reveal an increase in 2016 and 2017. This explains that the practice of corruption is experiencing a surge despite international efforts. Notwithstanding the existence of several anti-corruption measures in some countries in general and post-independent African states in particular, the rate of corruption continues to worsen in a few others. The lowest scoring index countries in Africa are mostly those with conflicts and dictatorial systems. Combating corruption in these contexts is often more challenging especially in cases where there is lack of rule of law and effective institutions to ensure accountability. This poses a great challenge to global peace, human rights and sustainable development.

Thus, the fragile nature of the African government's efforts in combating corruption presents real challenges to making meaningful changes or transformation within the African continent in general and Cameroon in particular. The poor record of fighting corruption in Cameroon is being influenced by poor administration, ineffective enforcement mechanisms, weak observance of human rights, and lack of effective separation of powers within the administrative system to carry out checks and balances and government's failure to meet its affirmative legal obligations to provide corruption-free services to ordinary citizens. The danger posed by corruption to global peace, human rights and sustainable development has further influenced the comity of states to raise awareness to curb corruption.

\section{Impact of Corruption and Measures to Combat Corruption}

Corruption, as stated in earlier, is a criminal offence which poses a great danger to sustainable development, human rights and peace. As stated in the 2030 Agenda for Sustainable Development, states are determined to foster peaceful, just and inclusive societies which are free from fear and violence. This is because there can be no sustainable development without peace and no peace without sustainable development (See recital 8, Preamble to the 2030 Agenda for Sustainable Development Goals). These fundamental principles (peace, human rights and development) are intrinsically linked to one another in such a way the development of one will lead to the positive realisation of another. While peace refers not only to the absence of war or violence(Galtung,1969) but also to the enjoyment of all socio-economic rights, sustainable development implies development that meets the needs of the present without compromising on the ability of future generations to meets their own needs (International Institute for Sustainable Development, 1989). 
The practice of corruption brings about poverty and hunger and generates economic crisis which has a negative impact on development and employment. This may indirectly affect those who depend on employment to make ends meet as they may be forced to take bribes due to poverty. It is further argued that corruption contributes significantly to the deaths of millions of children across the African continent annually from entirely preventable diseases (Kolawole, 2014). As stated by the UNDP, it is estimated that $\$ 1.48$ billion is lost by African countries each year due to corruption and almost $\$ 1$ trillion is paid in bribes every year, globally (United Nations Development Programme, 2014-2017).

Apparently, corruption affects all aspects or sectors of organized society and endangers individual rights and freedom-from hindering the rule of law to peace and security to sustainable development (UNDP, 2014-2017). Recognising the detrimental aspects of corruption on sustainable development, human rights and peace and in an effort to address the growing nature of corruption around the globe, state parties at the World Conference on Human Rights reaffirmed the right to development, as a universal and inalienable right and an integral part of fundamental human rights (Art.10 Vienna Declaration and Programme of Action, 1993). According to them, the human person is the central object of development. This is so because development facilitates the enjoyment of all human rights, the lack of development may not be invoked to justify the abridgment of international human rights.

In an attempt to transform the world in general and post-independent Africa in particular, the UN Agenda for Sustainable Development requires all states to substantially combat corruption and bribery in all their forms and to develop effective accountable and transparent institutions at all levels to fight against corruption(Goal 16 of 2030 Agenda for Sustainable Development). Because of the growing threat of corruption on world peace, human rights and sustainable development, the international community sees the combating of corruption alongside counterterrorism as the only possible means towards the transformation of the African continent. As noted by the UN Deputy Secretary-General and the former Secretary-General of the United Nations:

Corruption defies and undermines fundamental human rights and exacerbates poverty. It deepens inequality by diverting money sorely needed for health care, education and other essential services in our societies to criminals and dishonest officials. Corruption exacerbates violence and insecurity. It can lead to dissatisfaction with public institutions, disillusion with the government in general and spirals of anger and unrest. It undermines institutions and the beliefs in the systems that we have created for these institutions and a dangerous phenomenon. It increases the costs of doing business, distorts markets and impedes economic growth. It is driven by and feeds criminal activity. It also results in malfunctioning state institutions and weak governance. It is a barrier to achieving the Millennium Development Goals and our work for a more equitable and prosperous world (Eliasonn, 2013, Bank Ki-Moon, 2015).

However, cognizant of its negative impact on peace, human rights and sustainable development, Article 5 of the UN Convention against Corruption obliges all state parties to establish and promote effective practices through administrative measures to fight against corruption (UN General Assembly Resolution 58/4, A/RES/58/4(2003). This is because corruption poses a threat to stability and security, undermines the institutions and values of democracy, ethnic values, and justice and jeopardises sustainable development and the rule of law. Moreover, in the African continent, the African Union states vehemently that corruption undermines accountability and transparency in the management of public affairs as well as socio-economic development in the continent. The African Convention against Corruption, therefore, obliges all state parties to respect democratic principles and institutions, the rule of law, good governance and human rights and to take effective measures to combat corruption (Principle 3 \&5 African Union Convention in Combating Corruption, 2003).

The Convention further requires all designated public officials to declare their assets during and after the assumption of office and during and after the term of office (Art.7 of the African Union Convention in Combating Corruption). While at the G20 Summit in Hamburg, Germany, members emphasised that since corruption remains a significant challenge to developed, emerging and developing states, the prevention and combating of corruption is an essential means to ensure sustainable development (G20 Summit High Level Principles on Organising against Corruption, 
2017). This requires taking into consideration all necessary measures and a more proactive approach not only from the global community of states but also from individual states through the adoption of anti-corruption legislation, policies and effective institutions to ensure accountability.

\subsection{Domestic Efforts in Combating Corruption}

Since the ratification of international laws in the fight against corruption, state parties undertake various obligations to ensure effective policies and the accountability of victims of corruption practices. These efforts, though inadequate, have proven realistic in some countries in Africa such as South Africa, Nigeria and Cameroon, to mention some. Prominent cases can be seen in South Africa whereby former President Jacob Zuma was charged with embezzling state funds to furnish his private apartment and is presently held accountable for corruption. This shows a clear sense of change for Africa and the existence of the rule of law and effective institutions of accountability. Although many countries in the continent have put in place new anti-corruption laws, strategies and institutions, these efforts seem to have little or no practical implementation. In Cameroon for instance, the situation is deplorable.

The government has instituted several measures to combat corruption and boost economic development through the enactment of anti-corruption commissions and institutions to investigate matters of corruption. In as much as this is true, to buttress that point of argument, it is important to note that development does not only depend on combating corruption but also on transparency, the rule of law, respect for human rights and good governance. The practice is considered a criminal offence in Cameroon ${ }^{1}$ and the Constitution requires all those appointed by the government to declare their assets before and after office. ${ }^{2}$ Although this approach sounds very promising to curb corruption among government officials, it is doubtful how effective this can be when it comes to the implementation process. This is because there is no special body created to oversee the implementation of the said provision in the constitution. The institution of several units such as the National Anti-Corruption Committee (CONAC), the Special Criminal Court (SCC), Operation Sparrow Hawk and the National Agency for Financial Investigation (NAFI) etc., shows government commitment to combat corruption in all its forms.

Although the work of these bodies has shown great commitment towards the eradication of corruption in Cameroon, the danger lies in the level of their independence so much so that any decision taken should be free from being a political one. Apparently, in the case of Marafa Hamidou Yaya (former Minister of Territorial Administration and Decentralisation), the applicant was found guilty of corruption and embezzlement of public funds and was sentenced to 20 years imprisonment by the national court on appeal. Although this could be seen as a move made by the government towards meeting its affirmative legal obligations in the fight against corruption, the action against Marafa was described by the UN Working Group on Arbitrary Detention as a political one and arbitrary (UNWGAD Case No.22/2016, A/HRC/WGAD/2016). This has subjected the various institutional bodies meant to fight corruption into questioning their independence and the legality of their decisions on corruption. Even though several cases of corruption against public officials have been proven, it is evident that some decisions and efforts of the governments to curb corruption are fragile and create room for more problems in the economic situation of the state. This is so because most of them, if not all, are being sentenced to long-term jail without recovering what was stolen and using it to enhance economic development. Ultimately, only the families of those accused keep enjoying the stolen wealth. Such measures pose more challenges for economic development and must be addressed effectively to guarantee sustainable development, peace and human rights.

\section{Challenges}

Corruption suppresses economic growth by increasing cost and undermines sustainable

\footnotetext{
${ }^{1}$ See sections $134-1$ and 312 of Law No.2016/007 of 12 July 2016 Relating to the Cameroon Penal Code.

2 See for instance section 66 of the Cameroon Constitution, 1996 as amended, See also law No.003/2006 of 25 January 2005 on the Declaration of property and Assets by those responsible for managing public assets.
} 
management of economic resources to enhance human rights, peace and sustainable development. One of the fundamental aspects of sustainable development is good governance, separation of powers and respect for the rule of law. Since 1960, post-independent Africa has engaged in several democratic reforms aimed at moving the continent towards a better future based on democracy, human rights, peace and sustainable economic development. Although some African states such as South Africa, Ghana and Nigeria, for instance, have managed to pave the way for democracy by moving completely from authoritarianism, others still see authoritarianism as the best form of government. This has given room for a continuous stay in power and the adoption of punitive and vague laws that will favour rather than hold them accountable for their wrongful actions and to crack down on those who stand against them. This has further created widespread insurrection from ordinary citizens who perceive a change in government as the only way to guarantee more opportunities for the youths and the future generation thereby leading to a crisis or conflicts. The end result has been internal crisis and violence in some countries as it is the case in D.R. Congo and Cameroon today leading to widespread economic stagnation, human rights abuse and social unrest thereby jeopardizing sustainable development.

Although I hesitate to emphasise that a change in government does not necessarily mean sustainable peace, human rights and development will be guaranteed, it is important to note that a positive change in such a situation will depend a lot on the new government in place in as much as he or she has the people's welfare at heart. Another important challenge is the lack of employment opportunities and poor or low salaries and impunity. It is but clear that poverty influences hunger and corruption. These two notions are directly linked to each other. A greater proportion of youths and university graduates nowadays in Africa are left unemployed while those employed are being paid insufficient salaries - far below the minimum wages, especially in the private sectors - and are thus, unable to bear the monthly expenses or afford the upkeep of their families. That is why most military officers have been accused of taking bribes (petty) because their salaries cannot meet their expenses, thereby forcing them to seek alternative sources of income with corruption as the fastest and cheapest option, rendering the system most corrupt.

Moreover, the lack of an effective and practical separation of powers in most African states, like Cameroon, for instance, has also given room for no accountability, transparency and effective checks and balances among the various branches of government. Similar to Cameroon, for instance, independent anti-corruption bodies are virtually non-existent in Angola and Guinea Equatorial. Although the law may safeguard the independence of anti-corruption bodies in some states like Nigeria, these safeguards are rarely effective in practice (Kolawole, 2014). Instead, the law empowers the executive arm of government with the absolute power to determine the functioning of all sectors. For instance, in the domain of press freedom, the media plays a crucial rule in denouncing corruption in all its forms and practices but due to lack of a free media or government control as is the case in Cameroon and Ethiopia, it is difficult for them to criticised governments or state officials on the count of corruption. Freedom of expression facilitates citizens' right to participate in their own government, and it is an important tool for preventing and combating corruption, since it allows and encourages information-sharing concerning corruption and empowers journalists to investigate and educate the public about such cases. But restrictions on the right to freedom of expression through the use of draconian and defamation or sedition laws make it difficult for the media to perform it important role of exposing corruption in most African states. This has rendered the enforceability of the rule of law a misleading notion within most African states and a future blessed with uncertainty towards sustainable peace, human rights and economic development in post-independent Africa.

\section{Conclusion}

The paper argues that combating corruption is the only way forward for a positive transformation in post-independent Africa and Cameroon in particular. It argues that corruption impedes sustainable development, human rights and jeopardizes global peace. The act is deeply rooted in the bloodstream of almost every citizen as it is looked upon as the only way to facilitate bureaucratic administrative procedures and to boost economic wealth due to insufficient income or salaries. 
Many will agree that the greatest problem faced by Africa today is the high rate of unemployment among its youths and underdevelopment. This is due to mismanagement of economic resources by state officials and a failure of the governments to engage in effective meaningful democratic reforms that will create more jobs and cut down unemployment and poverty in the continent. This requires a more proactive and a determinate approach towards the effective implementation of the 2030 Agenda for Sustainable Development.

African states and Cameroon, in particular, must engage in effective policies and institutional reforms to effectively combat corruption. This requires a new way of thinking and practice and a movement from authoritarianism to democracy where institutional reforms will be able to enjoy absolute power and independence in every decision-making process and be able to hold governments accountable for corrupt practices and their wrongful acts as required by law. This transformative process demands a new mindset on how post-independent Africa sees sustainable development as a tool for a positive change that will put an end to poverty, underdevelopment, unemployment and illegal immigration of its citizens to Europe and a future blessed with hope, sustainable peace, human rights and development.

\section{References}

Bamidele, O. (2013). Corruption, Conflict and Sustainable Development in African States. The African Symposium 13(1): 42-51.

Bank Ki, M. (2015). Message on International Anti-Corruption Day (09 December 2015) $<$ https://www.unodc.org/1po-brazil/en/frontpage/2015/12/05-message-from-un-secretary-general-ban-kimoon-on-international-anti-corruption-day.html> accessed 04 May 2018

Cameroon Bar Association. (2015). Report on Human Rights in Cameroon (1st edn, Cameroon: Cameroon Human Rights Commission of the Cameroon Bar).

Eliasonn, J. (2013). 'Remarks on International Anti-Corruption Day High- Level Plenary: 'The Role of Good Governance and the Post-2013 Development Agenda https://www.un.org/sg/en/content/sg /statement/2013-12-09/secretary-generals-remarks-international-anti-corruption-day-high accessed 4 May 2018.

Fombad Charles, M. (2008). 'Cameroon's Constitutional Conundrum: Reconciling Unity with Diversity' in Ethnicity, human Rights and Constitutionalism in Africa (Kenya: The Kenya Section of the International Commission of Jurists) 121-155.

Fombad Charles, M. (2000) 'Endemic Corruption in Cameroon: Insight on Consequences and Control' in Kempe Rolnald Hope Sr and Bornwell C. Chikulo (eds), Corruption and Development in Africa: Lessons from Country Case-Studies (Great Britain: Macmillan Press LTD) 236-237.

Ferim, V. (2010). One-party domination, a flaw in Africa's democracy: Comparative Cases from Cameroon and South Africa. African Journal of Political Sciences and International Relations 7(7): 304-309.

Galtung, J. (1969). Violence Peace and Peace Research. Journal of Peace Research, 6(3): 167191.

Hailbronner, M. (2016). 'Overcoming Obstacles to North-South dialogue: Transformative Constitutionalism and the Fight against Poverty and Institutional Failure'. 49 Verfassung und Recht in Übersee, 49: 253.

International Institute for Sustainable Development, (1989). 'Report of the World Commission on Environment and Development: Our Common Future'< http://www.un-documents.net/our-common-future.pdf> accessed 8 May 2018

Kimaro, L. (2014). Combating Corruption: A Challenge to Faith Based Organisations in Contemporary Africa in Elizabeth Nduku and John Tenamwenya (eds) Corruption in Africa: A Threat to Justice and Sustainable Peace (Globethics.Net) 303-321.

Kolawole, O (2014). Corruption and Human Rights Law in Africa(UK: Hart Publishing Ltd 2014).

Patrick Lumumba Loch. O, (2014). Corruption: the Bane of Africa in Elizabeth Nduku and John Tenamwenya (eds) Corruption in Africa: A Threat to Justice and Sustainable Peace (Geneva: Globethics. Net) 1-46.

Tavanti M, (2013). Sustainable Solutions for Human Security and Anti-Corruption: Integrating Theories and Practices. International Journal of Sustainable Human Security, Vol.1:117.

Transforming our World: The 2030 Agenda for sustainable Development: Resolution adopted by the UN General Assembly 25 September 2015, A/RES/70/1(2015).

Transparency International, (2018). The Declaration Against Corruption <https://www.transparency.org /Declaration/en> accessed 28 February 2018.

Transparency International, (1996). Corruption Perception Index <https://www.transparency.org/Files /content/tool/1996_CPI_EN.pdf> accessed 04 May 2018. 
Transparency International, (2017). Corruption Perceptions Index <https://www.transparency.org/news /feature/corr-uption_perceptions_index_2017> accessed 03 May 2018.

United Nations Development Programme, (2014-2017). Global Anti-Corruption Initiative (New York: UNDP 2014-2017).

United Nation Development Programme,(2016).Support to the Implementation of the Sustainable Development Goals' (UNDP 26 January 2016) <htt://www.undp:org/content/undp/en/home/susta-inable-developmentgoals/goals-16-peace-justice-and-strong-institutions/ targets.html> accessed 4 May 2018. 